\title{
Antibacterial Activity Test of Extracts and Fractions of Cassava Leaves (Manihot esculenta Crantz) against Clinical Isolates of Staphylococcus epidermidis and Propionibacterium acnes Causing Acne
}

\author{
Resmi Mustarichie $\mathbb{D}^{1},{ }^{1}$ Sulistiyaningsih Sulistyaningsih, ${ }^{2}$ and Dudi Runadi ${ }^{2}$ \\ ${ }^{1}$ Pharmaceutical Analysisi and Medicinal Chemistry Department, Faculty of Pharmacy, Farmasi Universitas Padjadjaran, \\ Sumedang 45363, Indonesia \\ ${ }^{2}$ Biology Pharmacy Department, Faculty of Pharmacy, Universitas Padjadjaran, Sumedang 45363, Indonesia
}

Correspondence should be addressed to Resmi Mustarichie; resmi.mustarichie@unpad.ac.id

Received 21 May 2019; Revised 8 November 2019; Accepted 27 November 2019; Published 29 January 2020

Academic Editor: Joseph Falkinham

Copyright ( 2020 Resmi Mustarichie et al. This is an open access article distributed under the Creative Commons Attribution License, which permits unrestricted use, distribution, and reproduction in any medium, provided the original work is properly cited.

\begin{abstract}
This study is aimed at determining antibacterial activity from ethanol extracts and the most active fraction of cassava leaves against clinical isolates of Staphylococcus epidermidis and Propionibacterium acnes. Research carried out by the experimental method involved determination of plants, extraction with maceration method, fractionation with liquid-liquid extraction, antibacterial activity testing of extracts and fractions by agar diffusion method, determination of most active fraction from the extract, and minimum inhibitory concentration (MIC) and minimum bactericidal concentration (MBC) testing of most active fraction by microdilution method. The results showed that ethanol extracts of cassava leaves had antibacterial activity against both bacteria with the most active fraction indicated by ethyl acetate. MIC values of ethyl acetate fraction against $S$. epidermidis were in the concentration range of $2.5 \%-5.0 \%(\mathrm{w} / \mathrm{v})$ and against $P$. acnes were in the concentration range of $1.25 \%-2.5 \%(\mathrm{w} / \mathrm{v})$. The MBC value of ethyl acetate fraction against $S$. epidermidis was at a concentration of $5 \%(\mathrm{w} / \mathrm{v})$, while $P$. acnes was at a concentration of $2.5 \%(\mathrm{w} / \mathrm{v})$. From the results of this study, it can be concluded that the ethanol extract of cassava leaves (Manihot esculenta Crantz) has antibacterial activity against clinical isolates of Staphylococcus epidermidis as well as on Propionibacterium acnes. The fraction with the best activity from the ethanol extract of cassava leaves to the two test bacteria was shown by ethyl acetate fraction. It is suggested that cassava leaves are possible to be developed into standardized antiacne herbal.
\end{abstract}

\section{Introduction}

Acne vulgaris or acne is a chronic inflammatory disease of pilosebaceous follicles characterized by the appearance of blackheads, papules, pustules, and nodules [1]. Acne vulgaris results from a disturbance of keratinization accompanied by blockage of sebum flow produced by oil glands in the hair follicle ducts and primary acne efflorescence arising from blackheads or boils that protrude on the surface of the skin [2]. The site of the spread of the disease is limited to the pilosebaceous follicles on the face, chest, and back because the sebaceous glands in this area are very active $[3,4]$. The prevalence of zits varies depending on age and sex. The incidence of acne vulgaris ranges from $85 \%$ and occurs at the age of 14-17 years in women and 16-19 years in men, with predominant lesions being blackheads and papules. Acne can occur in children aged 9 years, but the peak is in men, especially those aged 17-18 years while women aged 16-17 years. Acne vulgaris is generally more common in men than women in the age range of $15-44$ years, i.e., $34 \%$ in men and $27 \%$ in women [5].

Microbial colonization in the sebaceous gland, such as Gram-positive bacteria $S$. epidermidis and $P$. acnes can potentially cause acne in certain conditions. These bacteria are 
not pathogenic under normal conditions, but if there are abnormal skin conditions, such as blockages in the ducts of the pilosebaceous gland secretion and increased production of sebum, then these bacteria turn into invasive $[6,7]$. Invasive $S$. epidermidis and $P$. acnes can produce lipolytic enzymes that convert sebum fractions into dense periods that damage hair follicles, causing comedogenic and inflammatory effects on the skin surface $[8,9]$. Until now, there have been no healing methods that completely treat acne. Although there are methods of antibacterial treatment with topical use of synthetic antibiotics such as clindamycin, tetracycline, and erythromycin $[10,11]$, but along with improper use of antibacterial agents (especially antibiotics) for a long time, there is an increasing development of microorganisms that cause disease, causing new types of bacteria that are resistant to antibiotics [12]. Therefore, it is necessary to look for alternative treatments, one of which is the use of herbal plants that have the potential as antibacterial.

As a tropical country, plants are one of the richest natural resources in Indonesia. Among the many types of plants that exist, cassava (Manihot esculenta Crantz.) is one of the plants used in everyday life. In Indonesia, cassava is a food ingredient that is widely consumed by the community and is a staple food in several regions after rice and corn. In addition to the utilization of cassava tubers as a staple food, cassava leaves are also used by ordinary people to overcome and treat ulcer disease, rheumatism, gout, diarrhea, fever, headache, night blindness, intestinal worms, and beri-beri disease [13]. Based on several scientific studies that have been carried out, cassava leaves are known to have chemical constituents including carbohydrates, calcium, phosphorus, fat, protein, vitamin $A$, vitamin B1, vitamin B2, vitamin C, water, substances, iron, flavonoids, saponins, and triterpenoids [14-16]. Flavonoid and saponin compounds are known to have antimicrobial and antiviral activity. Likewise, triterpenoids are known to have antiviral and antibacterial activity and can treat damage to the skin [17]. Other studies that have been conducted on cassava leaves include routine level checks, exploration of chlorophyll content as a basic food supplement, utilization in the wound healing process, anti-inflammatory, antioxidants, anticancer, and larvicide of mosquito Aedes aegepti; however, scientific studies so far relating antibacterial activity to ethanol extract of cassava leaves $M$. esculenta are still limited [18-20].

On the basis that so far there are no articles that discuss the antibacterial activity of cassava leaves extracted against $S$. epidermidis and $P$. acnes; this study reports scientific information about the benefits of extracts and fractions of cassava leaves as substances that have the potential to have antibacterial activity against $S$ epidermidis and $P$. acnes which cause acne.

\section{Materials and Methods}

2.1. Materials. Cassava plants were obtained from Lembang, West Java and determined in the taxonomy laboratory, Department of Biology, FMIPA-Universitas Padjadjaran.
2.2. Chemicals. Fuxine water, Dragendorff reagent, Lieberman-Buchard reagent, and Mayer reagent were used. If not stated otherwise, all chemicals were of analytical grades.

2.3. Medium for Bacterial Growth. Mueller Hinton Agar (Oxoid, Basingstoke, UK) and Mueller Hinton Broth (Oxoid, Basingstoke, UK) were used.

2.4. Microbial Test. S. epidermidis and P. acnes clinical isolates were used.

2.4.1. Preparation and Sterilization of Medium. $38 \mathrm{~g}$ of Mueller Hinton Agar (MHA) was dissolved in $1 \mathrm{~L}$ of distilled water, $21 \mathrm{~g}$ of Mueller Hinton Broth (MHB) was dissolved in $1 \mathrm{~L}$ of water, and then physiological $\mathrm{NaCl}$ was prepared for the bacterial suspension, thus making the medium. Then, the medium was sterilized in an autoclave at $121^{\circ} \mathrm{C}$ for \pm 15 minutes.

2.4.2. Tools. Tools such as a thin-layer chromatography set (Camag), toluene distillation equipment (Barnstead), incubator (Sakura IF-4), $254 \mathrm{~nm}$ and $366 \mathrm{~nm}$ UV lamps (Camag), refrigerator (Electrolux), 96-well microplate (Iwaki), light microscope (Nikon), analytic balance (Mettler Toledo), and glass which were commonly used in Laboratory of Pharmaceutical Microbiology, Universitas Padjadjaran.

2.4.3. Methods. The study began with material collection and plant determination by selecting cassava leaves, which were not affected by pests, collected, sorted, and dried until it beccome a sample [21, 22].

2.4.4. Extraction. Cassava leaves were macerated using $96 \%$ ethanol. The selection of this method was done to prevent the occurrence of damage to the thermolabile chemical compounds contained in the cassava leaves. The maceration was carried out by soaking the sample in the macerator and then leaving it for 24 hours at room temperature along with occasional stirring. The solvent replacement was carried out during $3 \times 24$ hours [23-25].

2.5. Phytochemical Screening. Phytochemical screening was carried out to detect secondary metabolites in the sample and ethanol extract of cassava leaves. Screening is carried out by the method stated in the Biological and Phytochemical Screening of Plants [26].

2.6. Extract Parameters. Testing the sample standard parameters included organoleptic test, water content determination, drying losses, water-soluble and ethanol extract content, total ash content, water-soluble ash content, and acid-insoluble ash content. Tests of extract parameters included organoleptic test, water content determination, 
drying losses, water-soluble extracts, and ethanol. The procedure was carried out according to what is stated in the attachment of Indonesian Herbal Pharmacopoeia Edition I [27].

2.7. Bacterial Identification Test. Test of bacterial affirmation test included observation of colony morphology, Gram staining, and biochemical tests.

2.8. Antibacterial Activity Test Extract. The antibacterial activity test of cassava leaf extract was carried out by the diffusion method using the perforation technique. A total of $20 \mu \mathrm{L}$ of each test bacterial suspension was put into sterile Petri dishes, and then $20 \mathrm{~mL}$ of sterile MHA was still added (temperature $45-50^{\circ} \mathrm{C}$ ). The mixture is homogenized, and then allowed to solidify at room temperature. Culture media that have solidified are perforated using holes. In each of these holes, $50 \mu \mathrm{L}$ of ethanol extract of cassava leaves were added with concentrations of $30 \%, 20 \%, 10 \%$, and $5 \%(\mathrm{~b} / \mathrm{v})$ using a micropipette. The test media were then incubated in an incubator at $37^{\circ} \mathrm{C}$ for $18-24$ hours and then measured the diameter of the inhibition zone formed using a caliper.

2.8.1. Fractionation. Fractionation of the extract was carried out by the liquid-liquid extraction (LLE) method using two solvents that were not mixed [28]. Thick fractions of n-hexane, ethyl acetate, and water were obtained. All fractions are observed in the organoleptic form including the color odor and then calculated the yield of each fraction by the formula:

$$
\text { Fraction yield }(\% w / w)=\frac{w t \text { fraction }}{\text { s sample }} 100 \% \text {. }
$$

2.9. Fraction Antibacterial Activity. The antibacterial activity of cassava leaf fraction was carried out by the diffusion method using a perforation technique such as in the antibacterial activity of extracts. The test was carried out using the smallest concentration which still provided activity in testing the extract. The most active fraction of the ethanol extract of cassava leaves was determined by the diameter of the largest inhibition zone.

\subsection{Determination of Minimum Growth Inhibitory Con-} centration (MIC) and Minimum Bactericidal Concentration $(M B C)$. Determination of MIC and MBC fraction of the ethanol extract of cassava leaves against $S$. epidermidis and $P$. acnes clinical isolates was carried out by the microdilution method [29]. Columns 1-12 of the microdilution plate are filled with $100 \mu \mathrm{L} \mathrm{MHB}$. The first column is the negative control, the second column is the negative fraction control (MHB and fraction), and the twelfth column was the positive control (MHB and test bacteria). Column 3 was filled with $100 \mu \mathrm{L}$ of the most active fraction at a concentration of $10 \%$. The dilution process was done by piping $100 \mu \mathrm{L}$ from the $3 \mathrm{rd}$ column to the 4 th column. This process was done repeatedly until column 11 , and then $100 \mu \mathrm{L}$ of the final dilution results were removed. Therefore, the concentration of the microdilution plate (from 3rd to 11th column) would be obtained at $10 \%, 5 \%, 2.5 \%, 1.25 \%, 0.625 \%, 0.3125 \%, 0.15625 \%$, $0.078125 \%$, and $0.0390625 \mathrm{~b} / \mathrm{v}$. In columns 3 to $12,10 \mu \mathrm{L}$ of the test bacteria were inserted.

2.11. Determination of the Most Active Thin-Layer Extract and Fraction Chromatography Profiles. Determination of the thin-layer chromatography (TLC) profile was carried out to determine the profile of the compounds contained in the extract and the most active fractions. The stationary phase used was GF 254 silica gel, and the mobile phase was n-butanol: acetic acid: water with a ratio of $4: 1: 5$. At the initial line (within $0.5 \mathrm{~cm}$ from the edge), the silica gel plate was $5 \mathrm{~cm} \times 2 \mathrm{~cm}$, the ethanol extract was bottled, and the most active fraction was using capillary pipes. The spots obtained were then observed in visible light, $254 \mathrm{~nm} \mathrm{UV}$ light, and $366 \mathrm{~nm}$ UV light and the Rf value was calculated.

\section{Results and Discussion}

3.1. Extraction Results. Extract of cassava leaves was carried out using the maceration method by soaking 450 grams of sample using ethanol $96 \%$ solvent at room temperature $\left(20^{\circ} \mathrm{C}-25^{\circ} \mathrm{C}\right)$. The maceration method was chosen by considering the components of secondary metabolites in sample. Extraction in this method used room temperature so that the decomposition of secondary metabolites could be avoided. 96\% ethanol solvent was used as a solvent because it could extract almost all secondary metabolites present in sample. This property was due to the presence of the $-\mathrm{OH}$ group which was polar, while the ethyl group $(\mathrm{CH} 3 \mathrm{CH} 2-)$ was nonpolar. With short carbon chains, ethanol was semipolar which was capable of dissolving nonpolar and polar secondary metabolites. Extraction was carried out 3 times with a take-up time of 24 hours storage [23-25]. This method was chosen because it was a fast, easy method and can remove solvents properly without damaging the secondary metabolites in the extract. The evaporation results that had been obtained were extracted and then stored in the evaporator cup and reheated on a water bath at a temperature of $30^{\circ} \mathrm{C}-40^{\circ} \mathrm{C}$ to remove the remaining residual solvents, until the thick extract period was obtained, and the yield was calculated. Of the $450 \mathrm{~g}$ of the sample used, the ethanol extract was $98.43 \mathrm{~g}$ so that the yield of ethanol extract of cassava leaves was $21.873 \%(w / w)$. The yield value was related to the number of secondary metabolites that were successfully extracted by comparing the weight of the extract to the weight of the sample [22]. Organoleptic observation showed that the extract was blackish-brown, distinctive smelling, and had bitter taste.

3.2. Phytochemical Screening. Phytochemical screening aimed to determine the secondary metabolites contained in sample and ethanol extract of cassava leaves with test results which can be seen in Table 1 . 
TABle 1: Phytochemical Screening of raw sample and ethanol extract of cassava leaves.

\begin{tabular}{lcc}
\hline Secondary metabolite & Sample & Ethanol extract \\
\hline Alkaloids & - & - \\
Flavonoids & + & + \\
Polyphenols & + & + \\
Tannin & - & - \\
Monoterpenoid and sesquiterpenoid & + & - \\
Steroids and triterpenoids & - & - \\
Quinone & + & + \\
Saponin & + & + \\
\hline
\end{tabular}

Description: $+=$ detected; $-=$ undetected.

Thiyagarajan and Suriyavathana reported their study on phytochemical and antimicrobial screening of $M$. esculanta Crantz varieties Mulluvadi and found their sample contained alkaloid and steroids [30]. The presence of antioxidant flavonoids and phenols was reported by Quartey et al. [31].Effect of boiled cassava leaves (M. esculenta Crantz) on total phenolic, flavonoid, and antioxidant activity was reported by Appiah et al. [32]. The difference in the results of the phytochemical screening analysis might be due to the origin of plants which were affected by soil nutrients in each region.

3.3. Standard Sample and Extract Parameters. The standard parameters of the sample tested included water content, water-soluble extract content, ethanol-soluble extract content, drying losses, total ash content, water-soluble ash content, and acid-insoluble ash content. As for the extract parameters, the procedure carried out was the same as the standard sample parameter, but without testing the ash content [27]. The results of testing the standard sample parameters and extracts can be seen in Table 2 .

From Table 2, it could be concluded that the water content of the extract was greater than the water content of the sample but still satisfies the water content of the extract according to Soetarno and Soediro which should not be more than $10 \%$ to avoid rapid growth of fungi and molds [33]. However, the presence of water content in ethanol extract showed that the evaporation process was poor. Tests for drying losses were carried out to provide maximum limits (ranges) about the number of compounds lost in the drying process. From the data in Table 2, after testing, the shrinkage of the sample was greater than the drying loss in the extract. This was because the sample used still had water content and other compounds that could be evaporated during the testing process at a temperature of $100-105^{\circ} \mathrm{C}$, resulting in a reduction in the total period of the sample after testing. Whereas in the extract, the drying shrinkage was smaller because the solvent used was mostly evaporated in the evaporation process. In testing the ash content in the sample, the principle was that the material was heated at a high temperature $\left(600^{\circ} \mathrm{C}\right)$ where the organic compound and its derivatives decompose and evaporate until only the organic mineral elements remain so that the determination of ash content aims to describe the internal and external mineral content in the sample, starting from the initial process until the extract was formed. The levels of acid-
TABLE 2: Standard sample and extract parameters.

\begin{tabular}{lcc}
\hline Standard parameter & $\begin{array}{c}\text { Concentrations } \\
\text { (\%) }\end{array}$ \\
& Sample & Extract \\
\hline Water content & 9.2 & 10.0 \\
The contents of the extract dissolved in water & 16 & 60 \\
The level of extract which was soluble in ethanol & 27 & 74 \\
Shrinkage drying & 12 & 11 \\
Total ash content & 13 & - \\
Levels of ash dissolved in water & 92.31 & - \\
Acid-insoluble ash level & 7.69 & - \\
\hline
\end{tabular}

soluble ash were examined to determine the level of the contents of calcium carbonate and alkali chloride, while the levels of acid-insoluble ash were examined to determine the level of contamination by metals and silicates. From the data in Table 2, after testing, the total ash content of the sample obtained was $13 \%$, of which $92.31 \%$ of the ash content was water-soluble and was $7.69 \%$ insoluble in acid. The purpose of testing the standard sample parameters and extract parameters was to standardize sample and determine extract quality. If the sample or extract from the same plant was tested again but if it gave different results, it was not necessarily the result of the test was wrong because the test results were influenced by compounds or substances contained in sample or extracts, which could be seen from testing the standard parameters. For example, the determination of soluble extracts of ethanol and levels of water-soluble extracts were specific parameters and parameters of total ash content were nonspecific parameters. The parameters of soluble extracts of ethanol and the levels of water-soluble extracts were said to be specific because they showed the solubility properties of the chemical compounds contained in the sample and extracts with a search using different solvents of polarity, while the nonspecific ash content parameters because the amount of metal contamination and the content of inorganic substances could differ even though the plants were the same depending on the place and condition of the test plant when taken so that it could reduce the test results or increase the test results. This was why it was necessary to test the standard sample and extracts, such as in herbal medicine and medicinal products from natural ingredients that had been on the market.

3.4. Identification of Test Bacteria. Before the antibacterial activity of the extracts was tested, a test of bacterial confirmation was carried out to ensure that the test bacteria were used. The bacteria used in this study were clinical isolates of S. epidermidis and P. acnes. First, the identification of the clinical isolates of $S$. epidermidis bacteria was carried out. The first identification was carried out by growing bacteria on the media to see the colony morphology of the test bacteria. From the results of bacterial growth on agar media, the $S$. epidermidis test bacteria grew with round, opaque, yellowish-gray colonies. These results were following the colony morphology found in the literature [34]. Next, Gram identification was done to separate the types of bacteria into Gram-positive bacteria and Gram-negative 
bacteria. From the results of microscopic observations of light at $1000 \mathrm{x}$ magnification, the test bacteria used were round-shaped like grapes and purple in color. This showed that the S. epidermidis bacteria used were included in the group of Gram-positive bacteria. These results were as per the literature which stated that $S$. epidermidis belong to Gram-positive bacteria [34]. Then, another affirmation test was carried out, namely, the biochemical test. This test was carried out to look at the biochemical properties of the test bacteria from their metabolic results against certain reagents after incubation at $37^{\circ} \mathrm{C}$ for $18-24$ hours. The biochemical test results gave different results for each bacterium, so it was necessary to do an affirmation test in addition to general Gram staining. The biochemical test results of S. epidermidis test bacteria can be seen in Table 3 .

From Table 3, it could be seen that, in the biochemical TSIA and Voges-Proskauer tests, the results shown in $S$. epidermidis clinical isolates were negative whereas in the literature, the results were shown in positive. Biochemical test results were slightly different from the literature because the bacteria used were clinical isolates so they had different characteristics when compared with the literature. Langlois et al. reported that existing species and biochemical characteristics tend to vary with sample sources and geographical regions [35]. Based on the results of this bacterial affirmation test, it could be concluded that the true test bacteria used were S. epidermidis bacteria. Then, the identification of the second test bacteria, $P$. acnes clinical isolates, was also carried out. The first identification was carried out by growing bacteria on the media to see the colony morphology of the test bacteria. From the results of bacterial growth on agar media, $P$. acnes test bacteria grew morphologically in the form of stems, opaque, and white in turbidity. The next identification was Gram staining. From the results of microscopic observations at 1000x magnification, the rodshaped bacteria were irregular and purple. This showed that the test bacteria used to belong to the group of Grampositive bacteria. Microscopic results and Gram staining of test bacteria can be seen in Table 4 .

From Table 4, it showed that the test results were the same as the test results found in the literature $[34,36]$ except in the glucose biochemical test, in which the results were shown in $P$. acnes clinical isolates were in negative, whereas in these textbooks, the results were shown in positive. However, negative glucose results from clinical isolates of $P$. acnes had also been reported by Polugari et al. [37]. As well as in our study, the use of clinically isolated P. acnes was not a pure $P$. acnes species that might be caused. Clinical isolate bacteria most likely had different characteristics from the original species. Based on the results of this bacterial affirmation test, it could be concluded that the actual bacteria used were $P$. acnes bacteria.

3.5. Antibacterial Extract Activity Test. It was found that the ethanol extract of cassava leaves at a concentration of 5\% showed no activity against the bacterial isolates of clinical $S$. epidermidis and still showed activity in clinical isolates of $P$. acnes. The greater the concentration of the extract solution, the greater the inhibition zone of the two test bacteria.

3.6. Extract Fractionation. Fractionation of ethanol extract of cassava leaves was carried out through a liquid-liquid extraction process (ECC), with the principle of the partition using solvents that did not mix, which aims to separate secondary metabolites in extracts based on their level of polarity [28]. It was found to possess 3 fractions, namely, $\mathrm{n}$-hexane fraction of yield of $1.302 \%$, ethyl acetate fraction of $0.348 \%$, and water fraction of $2.56 \%$. The organoleptic observations of the three fractions showed that the n-hexane fraction was solid, blackish green, distinctive smelling, and had bitter taste, ethyl acetate fraction in the form of blackishbrown thick solid, distinctive smell, and had bitter taste, while the water fraction was brown thick liquid blackish, distinctive smelling, and had bitter taste.

3.7. Fraction Antibacterial Activity. The results of the antibacterial activity tests of various fractions and ethanol extract of cassava leaves on clinical isolates of $S$. epidermidis and $P$. acnes are shown in Table 5.

From Table 5, it could be seen that the water fraction of the ethanol extract of cassava leaves did not show antibacterial activity against clinical isolates of $S$. epidermidis or $P$. acnes. The $\mathrm{n}$-hexane fraction showed only antibacterial activity at a concentration of $10 \%$ against $P$. acnes clinical isolates, whereas $S$. epidermidis clinical isolates showed no activity. Ethyl acetate fraction was the most active fraction because it had a larger inhibition zone both in clinical isolates of $S$. epidermidis and $P$. acnes compared with the other two fractions and ethanol extract as a comparison at a concentration of $10 \%$. The selection of the lowest concentration for testing fraction activity was based on the antibacterial activity test of ethanol extract. However, in testing the antibacterial activity of extracts with a concentration of $5 \%$, there was no activity against clinical isolates of S. epidermidis and its activity against clinical isolates of $P$. acnes was relatively small, so the second smallest concentration was used, i.e., $10 \%$, as a concentration test to facilitate observation of test results fraction activity. The diameter of the inhibition zone was a parameter of a compound or substance that can still influence the bacteria. The greater diameter of the inhibition zone indicates that the bacteria were still sensitive to an antibacterial substance. And conversely, the smaller diameter of the inhibitory zone indicated that the bacteria began to be resistant to the antibacterial substances or compounds tested [38].

3.8. Determination of the MIC and MBC of the Fraction. The results of MIC and MBC determination of ethyl acetate fraction, as the most active fraction, against $S$. epidermidis and $P$. acnes clinical isolates using the microdilution method are shown in Table 6.

The MIC value was obtained from the smallest concentration which still inhibited bacterial growth, in the microplate, shown by the first turbid concentration While 
TABLE 3: Biochemical test results of clinical isolates of S. epidermidis.

\begin{tabular}{lcc}
\hline Biochemical test & Clinical isolate of S. epidermidis & S. epidermidis [34] \\
\hline Motility & - & + \\
Glucose & + & + \\
Lactose & + & + \\
Mannose & + & + \\
Maltose & + & + \\
Saccharose & + & + \\
Triple sugar iron Agar (TSIA) & + & + \\
Urea & - & + \\
Methyl red (MR) & + & + \\
Voges-Proskauer (VP) & + \\
Citric & & + \\
\hline
\end{tabular}

Notes: +: reacted; - : not reacted.

TABLe 4: Biochemical test results of clinical isolates of P. acnes.

\begin{tabular}{lcc}
\hline Biochemical test & Clinical isolate of P. acnes & P. acnes [34, 36] \\
\hline Motility & - & - \\
Glucose & - & + \\
Lactose & - & - \\
Mannose & - & - \\
Maltose & - & - \\
Saccharose & + & + \\
Triple sugar iron agar (TSIA) & + & + \\
Urea & + & + \\
Methyl red (MR) & - & + \\
Voges-Proskauer (VP) & + & + \\
Citric & & + \\
\hline
\end{tabular}

Notes: +: reacted; - : not reacted.

TABle 5: Antibacterial activity fractions and ethanol extract of. cassava leaves to S. epidermidis and P. acnes clinical isolates.

\begin{tabular}{lccc}
\hline Test material & & Inhibition zone $(\mathrm{cm})$ & \\
& Concentration $(\% \mathrm{w} / \mathrm{v})$ & Clinical isolate of $S$. epidermidis & Clinical isolate of $P$. acnes \\
\hline The n-hexane fraction & 10 & - & 1.46 \\
Ethyl acetate fraction & 10 & 1.46 & 1.97 \\
Water fraction & 10 & - & - \\
Ethanol extract & 10 & 1.27 & $\mathbf{1 . 4 5}$ \\
\hline
\end{tabular}

The diameter of the capping hole $=0.9 \mathrm{~cm}$.

TABLE 6: MIC and MBC ethyl acetate fraction of cassava leaves.

\begin{tabular}{|c|c|c|c|c|}
\hline \multirow{4}{*}{ Concentration of ethyl acetate fraction (\% w/v) } & \multicolumn{4}{|c|}{ Bacterial growth } \\
\hline & \multirow{2}{*}{\multicolumn{2}{|c|}{$\begin{array}{l}\text { S. epidermidis } \\
\text { Clinical isolates }\end{array}$}} & \multirow{2}{*}{\multicolumn{2}{|c|}{$\begin{array}{c}\text { P. acnes } \\
\text { Clinical isolates }\end{array}$}} \\
\hline & & & & \\
\hline & Culture & Subculture & Culture & Subculture \\
\hline 10 & - & - & - & - \\
\hline 5 & - & - & - & - \\
\hline 2.5 & - & + & - & - \\
\hline 1.25 & + & + & - & + \\
\hline 0.625 & + & + & + & + \\
\hline 0.3125 & + & + & + & + \\
\hline 0.15625 & + & + & + & + \\
\hline 0.0781245 & + & + & + & + \\
\hline 0.0390625 & + & + & + & + \\
\hline
\end{tabular}

Description: $-=$ no bacterial growth; $+=$ bacterial growth. 


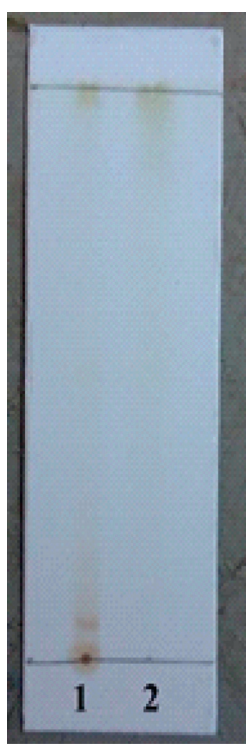

(a)

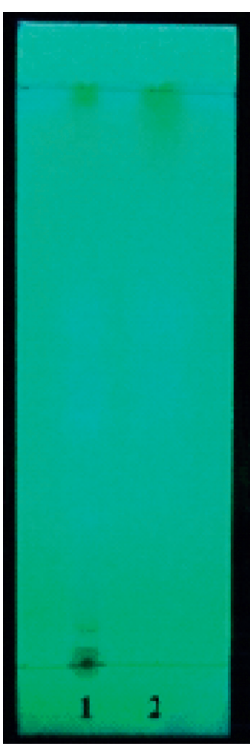

(b)

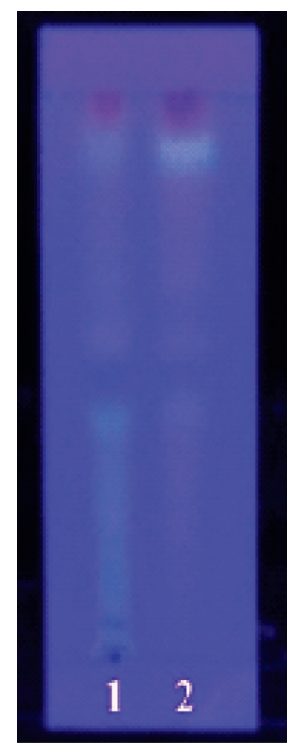

(c)

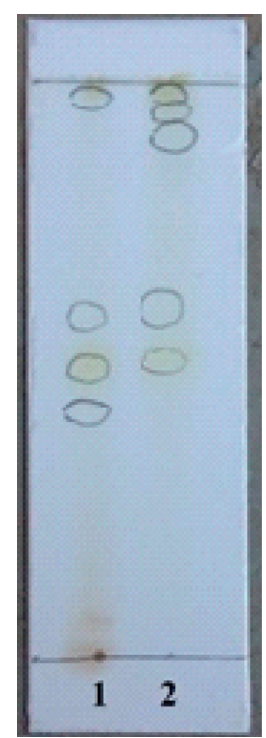

(d)

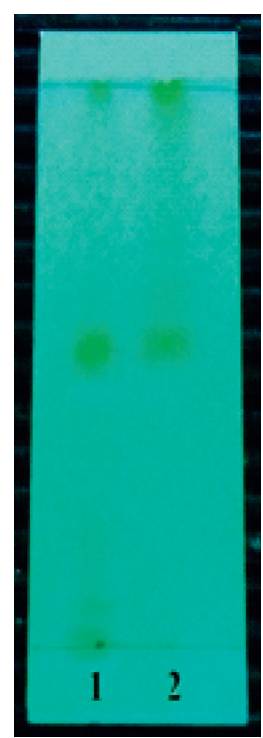

(e)

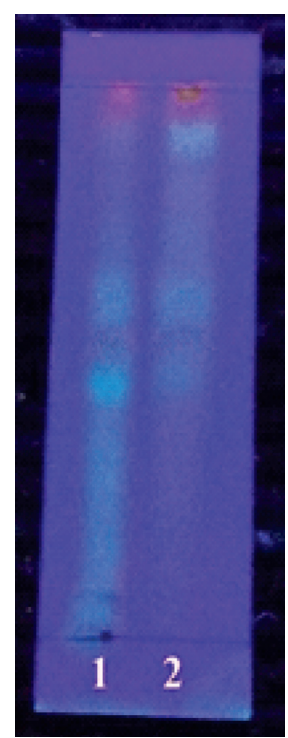

(f)

FIGURE 1: TLC profile of ethanol extract and ethyl acetate fraction of cassava leaves with the developer of n-butanol : acetic acid : water ( $4: 1$ : 5). (a) Visible light, (b) under UV $254 \mathrm{~nm}$, (c) under UV $366 \mathrm{~nm}$, (d) visible light + addition of $\mathrm{AlCl}_{3}$, (e) under UV $254 \mathrm{~nm}+$ addition of $\mathrm{AlCl}_{3}$, and (f) under UV $366 \mathrm{~nm}+$ addition of $\mathrm{AlCl}_{3} .1$ indicates ethanol extract, and 2 indicates ethyl acetate fraction.

the MBC value was obtained from the smallest concentration that was able to kill almost all bacterial colonies, which was shown by the concentration of last clear microplate. Table 6 (culture subheading) showed that the MIC value of cassava leaf ethyl acetate fraction against bacterial isolates of S. epidermidis was in the concentration range of $1.25-2.5 \%$ and those of $P$. acnes clinical isolates in the concentration range of $0.625-1.25 \%$. For MBC values of cassava leaf ethyl acetate fraction against bacterial isolates, S. epidermidis was at a concentration of $2.5 \%$ and clinical isolates of $P$. acnes at a concentration of $1.25 \%$. However, the interpretation of these results of the data under culture in the above table was not valid because the determination of MIC and MBC was based on the results of visualization on the microplate well by referring to the position where a significant fraction of the pigment changes in the well from brown to cloudy white. Therefore, after testing microdilution, a subculture of the MIC and MBC fractions of ethyl acetate fraction was carried out on the test bacteria to ascertain which concentrations were MIC and MBC, and the results under subculture of Table 6 were obtained. From the determination of MIC and MBC ethyl acetate fraction on culture and subculture results, it could be concluded that the MIC value of cassava leaf ethyl acetate fraction against bacteria $S$. epidermidis is in the concentration range of $2.5 \%-5 \%$ and $P$. acnes clinical isolates were in the concentration range of $1.25 \%-2.5 \%$. Whereas the $\mathrm{MBC}$ value of ethyl acetate fraction of cassava leaves to bacterial isolates of $S$. epidermidis was at a concentration of $5 \%$, and the clinical isolates of $P$. acnes were at a concentration of $2.5 \%$. The difference in interpretation of subculture data with the results on culture microplates was caused by turbidity of ethyl acetate fractions which still contained color pigments, so it was classified as undetectable (no bacterial growth) because the deposits at the base of the column in the MIC range during culture microplate observations could not be clearly seen.

\subsection{Determination of the Most Active Thin-Layer Chroma-} tography (TLC) Profile. Determination of thin-layer chromatography (TLC) profile was carried out to determine the profile of the compounds contained in ethanol extract and the most active fraction of ethyl acetate from cassava leaves. From the results of the optimization that had been done, it resulted in the use of the stationary phase of silica gel GF 254 and the mobile phase in the form of an eluent n-butanol mixture: acetic acid:water (4:1:5). Observations were carried out under visible light, $254 \mathrm{~nm}$ UV light, and $366 \mathrm{~nm}$ UV light, and then with the addition of reagents, the appearance of $\mathrm{AlCl} 3$ spots. The results of determining the TLC profile of ethanol extract and the ethyl acetate fraction of cassava leaves are shown in Figure 1.

As shown in Figure 1, it is known that the ethanol extract of cassava leaves had four spots observed under a $366 \mathrm{~nm}$ UV lamp with the RF of 0.45 (light blue); 0.525 (dark blue); 0.6125 (dark blue); and 0.9875 (purplish red). Ethyl acetate fraction of cassava leaves had five observed spots under the $366 \mathrm{~nm}$ UV lamp with the RF of 0.525 each (dark blue); 0.625 (dark blue); 0.925 (light green); 0.9625 (light green); and 0.9875 (purplish red). After the addition of $\mathrm{AlCl}_{3}$ to spots on the TLC plate, there were changes in color spots observed under UV lamps of $254 \mathrm{~nm}$ and $366 \mathrm{~nm}$, both in the spots of TLC extract of ethanol and in ethyl acetate fractions. This indicated that there was a reaction between the reagents of $\mathrm{AlCl}_{3}$ and the spot. The existence of color change reactions in spots might be due to the presence of flavonoid compounds that have free-hydroxyl groups and forms of complex bonds with the appearance of patches of $\mathrm{AlCl}_{3}$ on extracts and ethyl 
acetate fractions $[39,40]$. Other observed spots had compounds from secondary metabolite groups identified in the phytochemical sample (polyphenol and quinone groups in the results of TLC extract and ethyl acetate fraction and saponin groups in the TLC extract results).

All data mentioned in this study can be used as a support that cassava leaves can be developed as an antiacne herbal ingredient. The use of herbs as antiacne has been proposed by other researchers [41-43].

\section{Conclusions}

From the results of this study, it concluded that the ethanol extract of cassava leaves (M. esculenta Crantz) had antibacterial activity against clinical isolates of $S$. epidermidis as well as on $P$. acnes. The most active fraction of ethanol extracted from cassava leaves was shown by ethyl acetate fraction. The MIC value of ethyl acetate fraction against $S$. epidermidis bacterial isolates at the concentration range of $2.5 \%-5 \%(\mathrm{w} / \mathrm{v})$ and $1.25 \%-2.5 \%(\mathrm{w} / \mathrm{v})$. The MBC value of ethyl acetate fraction against $S$. epidermidis clinical isolates was at a concentration of $5 \%(\mathrm{w} / \mathrm{v})$, whereas clinical isolates of $P$. acnes was at a concentration of $2.5 \%(\mathrm{~b} / \mathrm{v})$. These results suggest that cassava leaves are possible to be developed into standardized antiacne herbal.

\section{Data Availability}

The MIC and the MBC data, as well as TLC data support this study.

\section{Conflicts of Interest}

The authors declare that there are no conflicts of interest regarding the publication of this paper.

\section{Acknowledgments}

The authors thank Agam Maulana for technical support.

\section{References}

[1] E. H. Aydemir, "Acne vulgaris," Türk Pediatri Arşivi, vol. 49, no. 1, pp. 13-16, 2017.

[2] C. C. Zouboulis, "Acne and sebaceous gland function," Clinics in Dermatology, vol. 22, no. 5, pp. 360-366, 2004.

[3] M. Picardo, L. F. Eichenfield, and J. Tan, "Acne and rosacea," Dermatology and Therapy, vol. 7, no. S1, pp. 43-52, 2017.

[4] M. Toyoda and M. Morohashi, "Pathogenesis of acne," Medical Electron Microscopy, vol. 34, no. 1, pp. 29-40, 2001.

[5] R. M. S. Tjekyan, "Acne vulgaris and its risk factors," Jurnal Kedokteran Media Medika Indonesia, vol. 43, no. 1, pp. 37-43, 2008.

[6] A. L. Cogen, V. Nizet, and R. L. Gallo, "Skin microbiota: a source of disease or defence?," British Journal of Dermatology, vol. 158, no. 3, pp. 442-455, 2008.

[7] B. Dréno, "What is new in the pathophysiology of acne, an overview," Journal of the European Academy of Dermatology and Venereology, vol. 31, no. S5, pp. 8-12, 2017.

[8] G. F. Webster, "Acne vulgaris," BMJ, vol. 325, no. 7362, pp. $475-479,2002$.
[9] W. M. Gübelin, A. Martinez, M. T. Molina, S. Zapata, and M. E. Valenzuela, "Antimicrobial susceptibility of strains of Propionibacterium acnes isolated from inflammatory acne," Microbiologia, vol. 48, no. 1, pp. 14-16, 2006.

[10] F. Mokhtari, G. Faghihi, A. Basiri, S. Farhadi, M. Nilforoushzadeh, and S. Behfar, "Comparison effect of azithromycin gel $2 \%$ with clindamycin gel $1 \%$ in patients with acne," Advanced Biomedical Research, vol. 5, p. 72, 2016.

[11] J. Pannu, A. McCarthy, A. Martin et al., "In vitro antibacterial activity of NB-003 against Propionibacterium acnes," Antimicrobial Agents and Chemotherapy, vol. 55, no. 9, pp. 4211-4217, 2011.

[12] J. K. Sutcliffe, "Antibiotic resistance of Propionibacterium acnes in Acne vulgaris," Dermatology Nursing, vol. 15, no. 4, pp. 359-362, 2003.

[13] H. Hasim, S. Falah, and L. K. Dewi, "Effect of boiled cassava leaves (Manihot esculenta Crantz) on total phenolic, flavonoid, and its antioxidant activity," Current Biochemistry, vol. 3, no. 3, pp. 116-127, 2016.

[14] A. O. Fasuyi, "Nutrient composition and processing effects on cassava leaf (Manihot esculenta Crantz) antinutrients," Pakistan Journal of Nutrition, vol. 4, no. 1, pp. 37-42, 2005.

[15] C. U. Okeke and E. Iweal, "Antioxidant profile of Dioscorea rotundata, Manihot esculenta, Ipomoea batatas, Vernonia amygdalina, and Aloe vera," Journal of Medical Research and Technology, vol. 4, pp. 4-10, 2007.

[16] O. A. T. Ebuehi, O. Babalola, and Z. Ahmed, "Phytochemical, nutritive and anti-nutritive composition of cassava (Manihot esculenta L) tubers and leaves," Nigerian Food Journal, vol. 23, no. 1, pp. 40-46, 2006.

[17] G. N. S. D. Silva, M. Primon-Barros, A. J. Macedo, and S. C. B. Gnoatto, "Triterpene derivatives as relevant scaffold for new antibiofilm drugs," Biomolecules, vol. 9, no. 2, pp. 58-69, 2019.

[18] S. Mohammad, M. A. Khan, A. Ali, L. Khan, M. S. Khan, and Z.-U.-R. Mashwani, "Feasible production of biomass and natural antioxidants through callus cultures in response to varying light intensities in olive (Olea europaea. L) cult. Arbosana," Journal of Photochemistry and Photobiology B: Biology, vol. 193, pp. 140-147, 2019.

[19] R. S. Kale and S. Bahekar, "Phytopharmacological aspects of Manihot esculenta crantz (cassava)- A review," Mintage Journal of Pharmaceutical \& Medical Sciences, vol. 2, no. 1, pp. 1-5, 2013.

[20] A. Al-Rofaai, W. A. Rahman, S. F. Sulaiman, and Z. S. Yahaya, "In vitro activity of neem (Azadirachta indica) and cassava (Manihot esculenta) on three pre-parasitic stages of susceptible and resistant strains of Teladorsagia (Ostertagia) circumcincta," Veterinary Parasitology, vol. 188, no. 1-2, pp. 85-92, 2012.

[21] M. Sirait, How to make Simplicia (Indonesian: Cara Pembuatan Simplisia), vol. 1-3, pp. 105-107, Direktorat Jenderal Pengawasan Obat dan Makana, Jakarta, Indonesia, 1985.

[22] Departemen Kesehatan Republik Indonesia (Depkes RI, General Standard Parameters of Medicinal Plant Extracts (Indonesian: Parameter Standar Umum Ekstrak Tumbuhan Obat), Depkes RI, Jakarta, Indonesia, 2000.

[23] R. Mustarichie, D. Ramdhani, and Y. Iskandar, "Characteristics and alopecia activity of pakis gajah (Angiopteris evecta (G.forst) hoffm.) growing in galunggung mountainside, West Java," Asian Journal of Pharmaceutical and Clinical Research, vol. 10, no. 11, pp. 337-340, 2017. 
[24] S. S. Handa, An Overview of Extraction Techniques for Medicinal and Aromatic Plants, pp. 21-54, International Centre for Science and High Technology, Trieste, Italy, 2008.

[25] V. Seindel, Natural Product Isolation, Springer, Berlin, Germany, 2005, http://www.springer.com/978-1-58829-447-0.

[26] N. R. Farnsworth, "Biological and phytochemical screening of plants," Journal of Pharmaceutical Sciences, vol. 55, no. 3, pp. 225-276, 1996.

[27] R. I. Depkes, Indonesian Herbal Pharmacopeia Jilid I, pp. 169-171, Departemen Kesehatan Republik Indonesia, Jakarta, Indonesia, 2008.

[28] M. Salem, M. Bernach, K. Bajdzienko, and P. Giavalisco, “A simple fractionated extraction method for the comprehensive analysis of metabolites, lipids, and proteins from a single sample," Journal of Visualized Experiments, vol. 124, no. 124, p. 55802, 2017.

[29] S. F. Kusuma, S. R. Mita, I. Firdayani, and R. Mustarichie, "Study on the antibacterial activity of fruit extracts of klutuk banana (Musa balbisiana Colla) against Shigella dysenteriae ATCC 13313," Asian Journal of Pharmaceutical and Clinical Research, vol. 10, no. 7, pp. 220-223, 2017.

[30] M. Thiyagarajan and M. Suriyavathana, "Phytochemical and antimicrobial screening of Manihot esculanta Crantz varieties Mulluvadi I, CO3 root bark," International Journal of Biotechnology and Biochemistry, vol. 6, no. 6, pp. 859-864, 2010.

[31] E. Quartey, H. Amoatey, E. Achoribo et al., "Phytochemical constituents and antioxidant activities in leaves of 14 breeding lines of cassava (Manihot esculenta Crantz)," American Journal of Experimental Agriculture, vol. 12, no. 5, pp. 1-10, 2016.

[32] H. Appiah, S. Falah, and L. K. Dewi, "Effect of boiled cassava leaves (Manihot esculenta Crantz) on total phenolic, flavonoid and its antioxidant activity," Current Biochemistry, vol. 3, no. 3, 2016.

[33] M. Angelina, P. Amelia, M. Irsyad, L. Lia Meilawati, and M. Hanafi, "Characterization of ethanol extract from katumpangan air herbs (Peperomia pellucida L. Kunth)," Biopropal Industri, vol. 6, no. 2, pp. 53-61, 2015.

[34] J. G. Holt, N. R. Krieg, P. H. A. Sneath, J. T. Staley, and S. T. Williams, Bergey's manual of determinative bacteriology, Lippincott, Williams \& Wilkins, vol. 532, pp. 547-548, Philadelphia, PA, USA, 9th edition, 2000.

[35] B. E. Langlois, R. J. Parlindungan, K. Harmon, and K. Akers, "Biochemical characteristics of Staphylococcus species of human and bovine origin," Journal of Food Protection, vol. 53, no. 2, pp. 119-126, 1990.

[36] S. Delgado, R. Cabrera-Rubio, A. Mira, A. Suárez, and B. Mayo, "Microbiological survey of the human gastric ecosystem using culturing and pyrosequencing methods," Microbial Ecology, vol. 65, no. 3, pp. 763-772, 2013.

[37] R. Polugari, S. R. Maria, and D. Shailaja, "Isolation and molecular characterization of acne-causing Propionibacterium acnes," International Journal of Scientific and Research Publications, vol. 6, no. 6, pp. 809-814, 2016.

[38] J. N. Flanagan and T. R. Steck, "The relationship between agar thickness and antimicrobial susceptibility testing," Indian Journal of Microbiology, vol. 57, no. 4, pp. 503-506, 2017.

[39] K. R. Markham, How to Identify Flavonoids, Translated to Indonesian by Kosasih Padmawinata, Penerbit ITB, Bandung, Indonesia, 1988.

[40] A. Suhendi, L. R. Sjahid, and D. Hanwar, "Isolation and identification of flavonoids from Dewandaru (Eugenia uniflora L.) leaf," Pharmacon, vol. 12, no. 2, pp. 73-81, 2011.
[41] H. Nasri, M. Bahmani, N. Shahinfard, A. Moradi Nafchi, S. Saberianpour, and M. Rafieian Kopaei, "Medicinal plants for the treatment of acne vulgaris: a review of recent evidences," Jundishapur Journal of Microbiology, vol. 8, no. 11, Article ID e25580, 2015.

[42] S. Kapoor and S. Saraf, "Topical herbal therapies an alternative and complementary choice to combat acne," Research Journal of Medicinal Plant, vol. 5, no. 6, pp. 650-669, 2011.

[43] M. Kanlayavattanakul and N. Lourith, "Therapeutic agents and herbs in topical application for acne treatment," International Journal of Cosmetic Science, vol. 33, no. 4, pp. 289-297, 2011. 